\title{
Measures of reversibility in response to bronchodilators in chronic airflow obstruction: relation to airway calibre
}

\author{
D C Weir, P Sherwood Burge
}

\begin{abstract}
A study was carried out to examine the independence from starting prebronchodilator $\mathrm{FEV}_{1}$ of four indices commonly used to express airflow $\left(\mathrm{FEV}_{1}\right)$ reversibility in response to bronchodilators. In 121 patients with chronic airflow obstruction with a mean prebronchodilator $F_{1} V_{1}$ of 1.81 (43.9\% of predicted values) the change in $F E V_{1}$ expressed as a percentage of the patient's predicted $F E V_{1}$ was the least dependent on starting FEV . Reversibility, expressed as a percentage of the prebronchodilator value or as a percentage of the maximal possible increase (predicted minus starting FEV $_{1}$ ) was correlated with starting $F_{E V_{1}}$.
\end{abstract}

Clinicians and research workers often measure the reversibility of airflow obstruction in response to bronchodilators. Treatment, inclusion in drug trials, and diagnostic labelling often depend on the result of such tests. The most informative way of expressing the results, however, is not clear. ${ }^{12}$ The most common way is to express the absolute improvement in forced expiratory volume in one second $\left(\mathrm{FEV}_{1}\right)$ as a percentage of the prebronchodilator value. When expressed in this way, however, small absolute changes in $\mathrm{FEV}_{1}$ become large percentage changes in patients with a low starting $\mathrm{FEV}_{1}$, so that those patients with the greatest impairment of lung function commonly appear to have the greatest reversibility. ${ }^{3}$ It has been suggested that expressing the reversibility as an index of the capacity to respond-(absolute change/ predicted $\mathrm{FEV}_{1}$ - prebronchodilator $\mathrm{FEV}_{1} \times$ 100)-is independent of the prebronchodilator treatment level and may in some circumstances be a more appropriate index of reversibility. ${ }^{4}$ This conclusion, however, was based on the results of a single test of response to an anticholinergic agent in a well defined homogeneous group of patients. We have examined the relation of this index and three other commonly used indices of reversibility in response to the prebronchodilator $\mathrm{FEV}_{1}$ in a heterogeneous group of patients with chronic airflow obstruction, measuring the response to both an anticholinergic agent, ipratropium bromide, and a $\beta_{2}$ agonist, salbutamol.

\section{Methods}

One hundred and twenty one outpatients, with a diagnosis of non-asthmatic chronic airflow obstruction and an $\mathrm{FEV}_{1}$ below $70 \%$ predicted, completed a trial to assess corticosteroid responsiveness. ${ }^{5}$ Reversibility of the $\mathrm{FEV}_{1}$ in response to $500 \mu \mathrm{g}$ ipratropium bromide and $10 \mathrm{mg}$ salbutamol was measured on different days during the 14 day run in period, before any corticosteroid was administered. Patients were asked to refrain from inhaled bronchodilators for six hours and oral bronchodilators for 24 hours before the laboratory visit. Each drug was given diluted in $2 \mathrm{ml}$ normal saline via an Inspiron Minineb driven by the same air compressor to dryness. FEV 1 was measured on a dry wedge spirometer (Vitalograph) before the drug was inhaled and 20 minutes (salbutamol) or 25 minutes (ipratropium) after nebulisation had finished. The mean of three technically satisfactory attempts within $10 \%$ or $100 \mathrm{ml}$ (whichever was the smaller) was used for subsequent analysis.

Reversibility of FEV 1 was expressed in four ways, as shown below:
Department of Respiratory Medicine, East Birmingham Hospital, Birmingham B9 5ST

D C Weir

P Sherwood Burge

Reprint requests to:

Dr Weir

Accepted 10 September 1990

1 as absolute change ( $\mathrm{ml}$ ) from the prebronchodilator value (absolute): postbronchodilator $\mathrm{FEV}_{1}$ - prebronchodilator $\mathrm{FEV}_{1}(\mathrm{ml})$

2 as a percentage of the initial prebronchodilator value ( $\%$ initial):

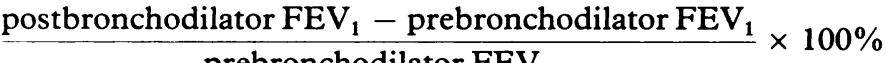

3 as a percentage of the predicted $\mathrm{FEV}_{1}$ ( $\%$ predicted): $\frac{\text { postbronchodilator } \mathrm{FEV}_{1} \text { - prebronchodilator } \mathrm{FEV}_{1}}{\text { predicted } \mathrm{FEV}_{1}} \times 100 \%$

4 as a percentage of the "possible" reversibility (\% possible): postbronchodilator $\mathrm{FEV}_{1}$ - prebronchodilator $\mathrm{FEV}_{1} \times 100 \%$ predicted $\mathrm{FEV}_{1}-$ prebronchodilator $\mathrm{FEV}_{1}$ 
Table 1 Mean (SEM) changes for each FEV, reversibility index in response to both drugs

\begin{tabular}{|c|c|c|}
\hline $\begin{array}{l}\text { Reversibility of } \\
F E V_{1}\end{array}$ & $\begin{array}{l}\text { Salbutamol } \\
10 \mathrm{mg}\end{array}$ & $\begin{array}{l}\text { Ipratropium } \\
\text { bromide } 500 \mu g\end{array}$ \\
\hline $\begin{array}{l}\text { Absolute }(\mathrm{ml}) \\
\% \text { initial } \\
\% \text { predicted } \\
\% \text { possible }\end{array}$ & $\begin{aligned} 208 & (19) \\
18.6 & (1 \cdot 5) \\
7.3 & (0.6) \\
16.0 & (1.7)\end{aligned}$ & $\begin{aligned} 216 & (18) \\
19.7 & (1.6) \\
8 \cdot 1 & (0.7) \\
18.6 & (2.3\end{aligned}$ \\
\hline
\end{tabular}

All negative change was classed as zero. Spearman ranked correlation coefficients were determined for each index. The prebronchodilator $\mathrm{FEV}_{1}$ was expressed as an absolute value and as a percentage of the predicted value. $^{6}$

\section{Results}

Of the 121 patients ( 27 female) studied, all had reversibility assessed in response to $10 \mathrm{mg}$ salbutamol and 119 in response to $500 \mu \mathrm{g}$ ipratropium bromide. The mean (SEM) age was $62(0.8)$ years and mean prebronchodilator $\mathrm{FEV}_{1} 1.18(0.04)$ litres $(43.9 \%(1.6 \%)$ predicted). The predicted FEV 1 ranged from 1.34 to 4.54 litres. One hundred and eight patients were current smokers or ex-smokers, with an average cigarette consumption of 770 (49) cigarette years.

The mean change in each index for both drugs is given in table 1 . Only 19 patients had a postbronchodilator $\mathrm{FEV}_{1}$ of more than $70 \%$ of the predicted value after salbutamol and 22 patients after ipratropium bromide. The correlation coefficients for the reversibility indices and prebronchodilator $\mathrm{FEV}_{1}$ expressed as an absolute value and as a percentage of the predicted value are shown in table 2 . Small but significant associations were seen between both $\mathrm{FEV}_{1}$ and $\mathrm{FEV}_{1}$ as \% predicted and reversibility expressed as $\%$ initial and $\%$ possible. This was true for both salbutamol and ipratropium bromide. When reversibility was expressed as absolute change and as \% predicted the values were not significantly associated with the prebronchodilator $\mathrm{FEV}_{1}$.

\section{Discussion}

Reversibility of $\mathrm{FEV}_{1}$ when expressed as a percentage of an individual's predicted FEV or as the absolute change was independent of starting $\mathrm{FEV}_{1}$ in this group of patients. In contrast to Postma et $a l_{,}^{4}$ we found a statistically significant association between reversibility expressed as a percentage of the capacity to respond (\% possible) and the prebronchodilator FEV $\mathrm{F}_{1}$. The most likely explanation for the differing findings lies in the selection of patients. Postma et al studied a selected group of patients with a homogeneous degree of airflow obstruction $\left(\mathrm{FEV}_{1} 1.2-2.5 \mathrm{l} / \mathrm{s}\right.$, an $\mathrm{FEV}_{1} / \mathrm{FVC}$ ratio of $40-55 \%$, and an improvement after thiazinium of less than $15 \%$ of prebronchodilator value). Our patient group was more heterogeneous for initial $\mathrm{FEV}_{1}$ and they were not selected according to criteria based on reversibility. Our findings therefore may be more generally applicable to patients with chronic airflow obstruction not thought to be due to asthma.

In the same study the Dutch group found a statistically independent influence of their reversibility index- $\% \mathrm{pr}-$ in (our \% possible)-on decline in $\mathrm{FEV}_{1}$ with time. ${ }^{4}$ In their own study and others, ${ }^{7}$ however, decline in $\mathrm{FEV}_{1}$ is inversely associated with the level of the initial $\mathrm{FEV}_{1}$. On the basis of our results it would be unwise to extrapolate their conclusions generally. In a group of patients similar to ours with a heterogeneous degree of airflow obstruction any relation between decline in $\mathrm{FEV}_{1}$ and reversibility expressed as a percentage of possible reversibility may be a consequence of the dependence of each on the initial FEV.

The choice of which index of reversibility should be used in a particular study will depend on the reason for investigating reversibility. Intuitively, an index free of dependence on another variable under study may seem generally most appropriate. If, however, the use of an $\mathrm{FEV}_{1}$ dependent variable gives additional useful information about the question under study-say, decline in lung function or treatment response-then the use of that variable will be justified. In all cases, however, the data on reversibility generated by a study should be examined for dependence on prebroncho-

Table 2 Spearman correlation coefficients (95\% confidence intervals) for reversibility indices and prebronchodilator $F E V_{1}$, expressed as absolute values and as percentages of predicted values

\begin{tabular}{|c|c|c|c|c|}
\hline \multirow{2}{*}{$\begin{array}{l}\text { Reversibility } \\
\text { of } F E V_{I}\end{array}$} & \multicolumn{2}{|l|}{$\begin{array}{l}\text { Salbutamol } 10 \mathrm{mg} \\
\mathrm{FEV}\end{array}$} & \multicolumn{2}{|c|}{$\begin{array}{l}\text { Ipratropium bromide } 500 \mu \mathrm{g} \\
F E V_{1}\end{array}$} \\
\hline & Litres & $\%$ predicted & Litres & $\%$ predicted \\
\hline Absolute & $\begin{array}{l}0.17 \\
(-0.01 \text { to } 0.34)\end{array}$ & $\begin{array}{l}0.03 \\
(-0 \cdot 15 \text { to } 0 \cdot 20)\end{array}$ & $\begin{array}{l}0.12 \\
(-0.06 \text { to } 0.29)\end{array}$ & $\begin{array}{l}0.08 \\
(-0.17 \text { to } 0.19)\end{array}$ \\
\hline$\%$ initial & $\begin{array}{l}-0.19^{\star} \\
(-0.36 \text { to }-0.01)\end{array}$ & $\begin{array}{l}-0.25^{\star} \\
(-0.08 \text { to }-0.41)\end{array}$ & $\begin{array}{l}-0.19^{\star} \\
(-0.36 \text { to }-0.01)\end{array}$ & $\begin{array}{l}-0.25^{\star} \\
(-0.41 \text { to }-0.07)\end{array}$ \\
\hline$\%$ predicted & $\begin{array}{l}0.11 \\
(-0.07 \text { to } 0.28)\end{array}$ & $\begin{array}{l}0.11 \\
(-0.07 \text { to } 0.28)\end{array}$ & $\begin{array}{l}0.07 \\
(-0.11 \text { to } 0.25)\end{array}$ & $\begin{array}{l}0.16 \\
(-0.02 \text { to } 0.33)\end{array}$ \\
\hline$\%$ possible & $\begin{array}{l}0.30^{\star} \\
(0.13 \text { to } 0.45)\end{array}$ & $\begin{array}{l}0.37^{\star} \\
(0.18 \text { to } 0.49)\end{array}$ & $\begin{array}{l}0.30^{\star} \\
(0.13 \text { to } 0.46)\end{array}$ & $\begin{array}{l}0.44^{\star} \\
(0.28 \text { to } 0.57)\end{array}$ \\
\hline
\end{tabular}

${ }^{\star} \mathrm{p}<0.05$. 
dilator $\mathrm{FEV}_{1}$. The relation of a particular index to prebronchodilator $\mathrm{FEV}_{1}$ may well vary with differing populations studied, depending on spread of $\mathrm{FEV}_{1}$ values, underlying diagnosis, age and sex distribution, and other factors. Using a measure which is independent of prebronchodilator $\mathrm{FEV}_{1}$, however, will facilitate comparisons between the results of different studies.

1 Anonymous. Assessment of airflow obstruction [editorial]. Lancet 1986;ii:1255-6.

2 Anonymous. Airflow limitation-reversible or irreversible? Lancet 1988;i:26-7.
3 Tweeddale PM, Alexander F, McHardy GJR. Short term variability in FEV, and bronchodilator responsiveness in patients with obstructive ventilatory defects. Thorax 1987;42:487-90.

4 Postma DS, De Vries K, Koeter GH, Sluiter HJ. Independent influence of reversibility of airflow obstruction and nonspecific hyperreactivity on the long term course of lung function in chronic airflow obstruction. $A m$ Rev Respir Dis 1986;134:276-80.

5 Weir DC, Gove RI, Robertson AS, Burge PS. Corticosteroid trials in non-asthmatic chronic airflow obstruction: a comparison of oral prednisolone and inhaled beclomethasone dipropionate. Thorax 1990;45:112-7.

6 Quanjer $\mathrm{Ph}$ (ed.). Standardised lung function testing. Bull Eur Physiopathol Respir 1983;19 (suppl 5):1-95.

7 Anthonisen NR, Wright EC, Hodgkin JE, and the IPPB tria group. Prognosis in chronic obstructive pulmonary disease. Am Rev Respir Dis 1986;133:14-20.

\section{BOOK NOTICES}

Respiratory Medicine. Edited by RAL Brewis, GJ Gibson, DM Geddes. (Pp 1559; £85.) London: Harcourt Brace Jovanovich, 1990. ISBN 0702012793.

Rarely is the opportunity presented to antagonise so many of one's colleagues-94 to be precise. Thankfully, I can let the opportunity slip because this new all British tex really does deliver the goods. A wealth of scientific information is combined with, in general, sound and often helpfully didactic clinical advice. The extensive referencing of each chapter (up to 1989 in some instances) is especially valuable. But this is more than just an excellent source book-it is a jolly good read. Time and again, when I had merely intended to look up a specific point, I found myself drawn to browsing through adjoining chapters. Sections on sleep related disorders, humidifier fever, and thoracoscopy for physicians, among others, give the book a leading edge feel; but even the traditional areas of airflow obstruction, lung cancer, and tuberculosis invigorate the reader. My only real concern arises from the book's traditional disease oriented approach, which on occasions does not lend itself to the difficulties of the chest physician faced with a clinical-radiographic syndrome, rather than a disease. The reader will not, for example, find an overall approach to the lung cavity, though the individual diagnostic possibilities are well covered in separate sections. Again, the text could have been more clinically directive in some areas; specific antibiotics in bronchiectasis and specific regimens for small cell lung cancer are not discussed, though I accept that this may be inappropriate when one is aiming at a worldwide market. Radiographic reproduction is generally good, but more use of pointers would have been helpful; too often with computed tomograms the reader is left wondering what or where the abnormality is. Just as Persian carpet weavers traditionally incorporated a mistake lest perfection should offend Allah, so publishers include the obligatory radiographs with text reversed to test whether reviewers have reviewed. Fortunately I found it, on page 231. Chapter 2.1 has lost its textural references. Minor criticisms aside, this is a "big" book in every sense. The editors and authors are to be congratulated in producing what I have little doubt wil be the foremost European respiratory textbook of its kind and one that will be a major contender worldwide.-IDA

Surgical Pathology of Lung Neoplasms. Edited by AM Marchevsky. (Pp 709; $\$ 180$.) New York: Dekker, 1990. ISBN 082478106 6.

This is the first edition of a book that is largely devoted to its surgical pathology of lung and pleural neoplasms but is supplemented by chapters on epidemiology, experimental models, and cytology. I found the supplementary chapters rather disap- pointing, particularly the epidemiological ones, which were very superficial. The statement on page 2 that "All forms of asbestos... have been shown to have the same risk for subsequent development of lung cancer after industrial exposure" oversimplifies the facts. I am not convinced that it was advisable to include these chapters in this book. The surgical pathology chapters provide comprehensive descriptions of the macroscope, microsopic, electron microscopic, and immunohistochemical features of a wide variety of lung neopolasms. The chapters are well referenced and up to date, though there is the odd missed reference-for example, Humphreys et al (1988), cited on page 372 , is not included in the list of references at the end of the chapter. The chapter on classification is disappointing because it merely reiterates the World Health Organisation classification and gives no comparison of the strengths and weaknesses between the classifications. An irritating feature of the presentation is the interruption of the text by several pages of illustrations, which are often well away from the page on which they are referenced to; in additon, many figures take up only half a page with blank space beneath them. On balance, I thought that the book was very useful as a straightforward, comprehensive, well illustrated account of pulmonary tumours and I have found it useful in my own laboratory when dealing with surgical resections. I have found it less useful, however, in dealing with small biopsy specimens.-ARG

A further book notice appears on page 76. 